\title{
PENGARUH PENGHARGAAN TERHADAP PERCEIVED ORGANIZATIONAL SUPPORT DAN KOMITMEN AFEKTIF KARYAWAN KOPERASI TAKSI BANDAR UDARA (KOPSIDARA) SULTAN HASANUDDIN
}

\author{
EKA SUHARTINI* \& AHMAD MUSAFIR A. \\ Jurusan Manajemen, FEBI UIN Alauddin Makassar
}

\begin{abstract}
ABSTRAK: Penelitian ini bertujuan untuk mengetahui pengaruh penghargaan terhadap komitmen afektif dengan perceived organizational support sebagai variabel intervening pada Koperasi Taksi Bandar Udara (KOPSIDARA) Sultan Hasanuddin. Teknik pengambilan sampel yang digunakan ialah teknik proportional random sampling. Analisis data menggunakan analisis jalur. Hasil penelitian ini membukitikan bahwa: 1) Penghargaan berpengaruh positif dan signifikan terhadap Komitmen Afektif;2) Penghargaan berpengaruh positif dan signfikan terhadap Perceived Organizational Support;3) Perceived Organizational Support berpengaruh positif dan signfikan terhadap Komitmen Afektif; 4) Perceived Organizational Support memediasi Penghargaan dan berpengaruh positif serta signifikan terhadap Komitmen Afektif.
\end{abstract}

Kata Kunci : Penghargaan, Perceived Organizational Support, dan Komitmen Afektif

ABSTRACT: This study aims to determine the effect of appreciation on affective commitment with perceived organizational support as intervening variable at the Airport Taxi Cooperative (KOPSIDARA) of Sultan Hasanuddin. The sampling technique used is proportional random sampling technique. Data analysis was path analysis. The results of this study indicate that: 1) Awards have a positive and significant effect on Affective Commitment; 2) Appreciation has a positive and significant influence on Perceived Organizational Support; 3) Perceived Organizational Support has a positive and significant influence on Affective Commitment; 4) Perceived Organizational Support mediates Award positively and significantly on Affective Commitment $(Y)$.

Keywords: Award, Perceived Organizational Support, and Affective Commitment

* Surel Korespondesi penulis: suhartinieka@yahoo.com

ISSN-E: 2597-6990

ISSN-P: 2442-4951

http://journal.uin-alauddin.ac.id/index.php/minds 


\section{PENDAHULUAN}

Keberhasilan suatu organisasi dalam mencapai tujuan bukan hanya ditentukan oleh banyaknya ketersediaan sumber daya alam, namun juga sangat ditentukan oleh kualitas sumber daya manusia. Potensi sumber daya manusia pada hakekatnya merupakan salah satu modal dasar dalam suatu organisasi yang mana sumber daya manusia adalah pelaksana kegiatan dalam organisasi yang mempunyai peranan penting dalam mencapai tujuan organisasi. Dengan kata lain sumber daya manusia adalah unsur kerja yang penting yang tidak dapat diperlakukan seperti unsur lainnya, karena sumber daya manusia selalu berperan aktif dan dominan dalam setiap kegiatan organisasi. Sumber daya manusia menjadi perencana, pelaku, dan penentu terwujudnya tujuan organisasi (Hasibuan, 2010:10). Oleh karena itu, peningkatan dan kualitas sumber daya manusia menjadi salah satu sasaran utama dalam pembangunan nasional.

Bergabungnya manusia kedalam perusahaan atau organisasi sebagai karyawan tentu disertai dengan berbagai harapan bahwa kebutuhannya dapat terpenuhi oleh perusahaan tersebut. Sebagai jasa atas keikutsertaannya dalam pemcapaian tujuan perusahaan, maka perusahaan memungkinkan untuk membayar para karyawan lebih dari sekedar gaji pokok saja, tetapi dimungkinkan pula untuk memberikan berbagai tunjangan, serta penghargaan baik yang bersifat materil maupun non materil sesuai dengan prestasi masingmasing.

Menurut Mulyadi dan Setyawan (2001: 239) penghargaan harus dihargai oleh penerima. Penghargaan yang tidak bernilai dimata penerima tidak akan memotivasi penerima untuk berprestasi. Penghargaan harus cukup besar untuk dapat memiliki dampak. Jika penghargaan yang disediakan jumlah tidak signifikan, dampaknya dapat berlawanan dengan usaha untuk meningkatkan produktivitas.

Dalam konsep manajemen, penghargaan merupakan salah satu alat untuk meningkatkan motivasi kinerja para karyawan. Menurut Nawawi: penghargaan ialah usaha menumbuhkan perasaan diterima (diakui) di lingkungan kerja, yang menyentuh aspek kompensasi dan aspek hubungan antara para pekerja yang satu dengan yang lainnya (Nawawi, 2005:119). Dari pendapat di atas bahwa penghargaan merupakan salah satu bentuk dari dukungan organisasi untuk mempertahankan karyawan. Perasaan dihargai oleh organisasi membantu mempertemukan kebutuhan karyawan akan persetujuan, penghargaan dan keanggotaan. Penilaian positif dari organisasi juga meningkatkan kepercayaan bahwa peningkatan usaha dalam bekerja akan dihargai. Oleh karena itu, karyawan akan memberikan perhatian yang lebih dari penghargaan yang mereka terima. Sehingga semakin besar penghargaan yang diberikan oleh organisasi maka akan semakin besar pula dukungan organisasi yang dirasakan oleh karyawan.

Dukungan organisasi yang sering dikenal dengan istilah "perceived organizational support" merupakan konsep yang penting dalam literatur manajemen karena dukungan organisasi memberikan penjelasan mengenai hubungan antara perlakuan organisasi, sikap dan perilaku karyawan terhadap 
pekerjaan dan organisasi mereka. Perceived Organizational Support dapat didefinisikan sebagai persepsi karyawan mengenai sejauh mana organisasi menilai kontribusi mereka dan peduli pada kesejehteraan mereka (Eisenberg \& Rhodes, 2002).

Pada penelitian yang dilakukan oleh Rhoades yang menggunakan sampel karyawan dari berbagai organisasi ditemukan bahwa karyawan yang merasa dirinya mendapatkan dukungan organisasi akan memiliki rasa kebermaknaan dalam diri karyawan tersebut hal inilah yang akan meningkatkan komitmen pada diri karyawan. Komitmen inilah yang pada akhirnya akan mendorong karyawan untuk berusaha membantu organisasi mencapai tujuannya, dan meningkatkan harapan bahwa performa kerja akan diperhatikan dan dihargai oleh organisasi(Eisenberg \& Rhodes, 2002).

Komitmen organisasi mencerminkan bagaimana seorang individu mengidentifikasikan dirinya dengan organisasi dan terikat dengan tujuan organisasi. Komitmen yang lebih tinggi dapat mempermudah terwujudnya produktivitas yang lebih tinggi. Telah banyak review mengenai teori-teori komitmen dilakukan oleh para ahli yang mengindikasikan kurangnya keterikatan karyawan yang akan mengakibatkan kurangnya efektifitas organisasi.

Defenisi tentang komitmen organisasi dalam berbagai literatur yang ada sering dikaitkan dengan keinginan untuk bertahan didalam organisasi. Menurut Kreitner dan Kinicki bahwa komitmen organisasi adalah kesepakatan untuk melakukan sesuatu untuk diri sendiri, individu lain kelompok atau organisasi. Menurut Schermerhorn, Hunt, Osborn, dan Uhl-Bein menyatakan komitmen organisasi sebagai loyalitas seorang individu kepada organisasi. Individu dengan komitmen organisasional yang tinggi mengindentifikasi diri secara kuat dengan organisasi dan merasa bangga mempertimbangkan dirinya sebagai anggota (Wibowo, 2014:428).

Meyer dan Allen membedakan komitmen organisasional menjadi 3 bentuk yaitu: afektif, normatif dan berkelanjutan. Komitmen afektif mencerminkan persasaan terikat, terindentifikasi dengan dan terlibat didalam organisasi. Komitmen normatif mencerminkan pada kepedulian terhadap biaya kaitan dengan apabila meninggalkan organisasi. Dan komitmen berkelanjutan mencerminkan perasaan sebagai kewajiban untuk melanjutkan kesempatan kerja (1991).

Seseorang dengan komitmen afektif lebih mungkin untuk mengembangkan perilaku yang sesuai dengan visi dan misi organisasinya, serta lebih mungkin untuk mengikuti perkembangan dalam pekerjaan. Berbeda dengan individu yang memiliki komitmen normatif dan berkelanjutan yang kuat, mereka biasanya kurang terlibat dalam aktivitas-altivitas keorganisasian maupun pekerjaan. Atas dasar itulah penelitian ini lebih memfokuskan pada komitmen afektif, karena sebagaimana yang telah diuraikan diatas bahwa komitmen organisasi afektif mengindikasikan loyalitas serta sikap individu karyawan untuk menjalankan tujuan dan nilai-nilai perusahaan tanpa adanya paksaan dan pamrih lain yang diharapkan. 
Koperasi Taksi Bandar Udara (KOPSIDARA) Sultan Hasanuddin merupakan salah satu badan usaha koperasi yang bergerak dalam bidang transportasi taksi yang menawarkan jasa tumpangan di Bandar Udara Sultan Hasanuddin. KOPSIDARA sebagai operator taksi terbesar di Bandar Udara Sultan Hasanuddin sangat membutuhkan komitmen yang kuat daripada karyawan maupun supir dengan mengedepankan pelayanan prima serta kinerja yang produktif.

Namun demikian, dalam upaya menciptakan komitmen karyawan maupun supir KOPSIDARA masih memiliki banyak kendala yang dihadapi sehingga sulit untuk mencapai tujuan organisasi. Dimana kendala yang dihadapi KOPSIDARA antara lain: (1) Kurangnya perhatian dari pimpinan terhadap karyawan maupun supir sehingga; (2) Banyaknya karyawan yang dipecat dan banyak pula yang mundur disebabkan oleh pimpinan yang sering mencurigai karyawan; (3)Tidak adanya kepercayaan dari pimpinan terhadap karyawan maupun supir; (4) Tidak menghargai pendapat dari karyawan sehingga karyawan merasa tidak dihargai.

Dari fenomena di atas bahwa hal tersebut mengakibatkan komitmen karyawan maupun supir menurun yang disebabkan kurangnya penghargaan maupun dukungan organisasi yang dirasakan oleh karyawan maupun supir. Rhoades dan Eisenberger berpendapat bahwa organisasi menghargai kontribusi dan peduli terhadap kesejahteraan karyawannya itu penting, namun penelitian menunjukkan bahwa para karyawan menggabungkan dukungan nyata yang ditunjukkan oleh organisasi dengan persepsi individual mereka. Para karyawan yakin bahwa organisasi mempunyai tujuan dan orientasi yang positif atau negatif terhadap mereka yang pada akhirnya akan berpengaruh pada penghargaan terhadap kontribusi dan kesejahteraan karyawan tersebut. Dan Jika karyawan menganggap bahwa dukungan organisasi yang di terimanya tinggi, maka karyawan tersebut akan menyatukan keanggotaan sebagai anggota organisasi ke dalam identitas diri mereka dan kemudian mengembangkan hubungan dan persepsi yang lebih positif terhadap organisasi tersebut (Eisenberg \& Rhodes, 2002).

Dalam kaitannya dengan komitmen karyawan, hal di atas tentunya harus segera dibenahi oleh pimpinan agar dapat memberikan penghargaan yang sesuai sehingga dukungan organisasi yang diterima oleh karyawan tinggi. Hal ini tentu akan meningkatkan komitmen afektif karyawan maupun supir yang akan meningkatkan pelayanan prima supir untuk merebut hati konsumen serta meningkatkan produktivitas karyawan. Penelitian ini dilakukan untuk mengetahui apakah penghargaan mempunyai pengaruh positif dan signifikan terhadap komitmen afektif dengan dimediasi oleh perceived organizatioanl support. Dengan adanya penelitian ini diharapkan dapat memberikan manfaat bagi organisasi dalam meningkatkan komitmen afektif karyawan sehingga menyatukan perasaan karyawan maupun supir untuk mengembangkan hubugan dan persepsi yang lebih positif terhadap organisasi. 


\section{Komitmen Afektif}

\section{TINJAUAN TEORITIS}

Setiap organisasi berusaha mencapai tujuannya dengan menggunakan segenap sumber daya yang dimiliki. Oleh karena itu, tujuan setiap sumber daya manusia dalam organisasi harus dijaga agar selaras dengan tujuan organisasi.

Di samping itu, sumber daya manusia dalam organisasi diharapkan memliki kompetensi, kemampuan, dan keterampilan yang diperlukan untuk melaksanakan tugasnya. Organisasi juga memerlukan sumber daya manusia yang memiliki motivasi berprestasi dan etos kerja keras, dan tidak kalah pentingnya adalah mempunyai komitmen kuat pada organisasi. Dengan demikian diharapkan sumber daya manusia organisasi dapat memberikan kontribusi terbaiknya pada organisasi.

Meyer dan Allen membedakan komitmen organisasional menjadi 3 bentuk yaitu: afektif, normatif dan berkelanjutan. Komitmen afektif mencerminkan persasaan terikat, terindentifikasi dengan dan terlibat didalam organisasi. Komitmen normatif mencerminkan pada kepedulian terhadap biaya kaitan dengan apabila meninggalkan organisasi. Dan normatif komitmen mencerminkan perasaan sebagai kewajiban untuk melanjutkan kesempatan kerja (Meyer \& Allen, 1991).

Pandangan pakar tentang pengertian komitmen afektif dapat sangat bervariasi. Menurut Greenberg dan Baron bahwa, komitmen afektif adalah kekuatan dari hasrat orang untuk tetap bekerja pada suatu organisasi karena mereka sepaham dengan nilai dan tujuan pokok organisasi (Hasmarini \& Yuniawan, 2008). Definisi komitmen afektif menurut Lease adalah kondisi dimana seorang karyawan mengidentifikasikan diri dengan organisasi dan tujuan dari organisasi dan berharap untuk tetap menjadi anggota dari organisasi tersebut.

Dari pendapat-pendapat tersebut dapat disimpulkan bahwa pada dasarnya komitmen afektif merupakan suatu ikatan emosional seorang karyawan pada pimpinan atau organisasi dengan menunjukkan sikap positif terhadap tujuan organisasi serta adanya keinginan untuk mempertahankan dalam organisasi.

\section{Perceived Organizational Support}

Bagi karyawan, organisasi merupakan sumber penting bagai kebutuhan sosio-emosional mereka seperti penghargaan, kepedulian dan tangible benefit seperti gaji dan tunjangan kesehatan. Perasaan dihargai oleh organisasi membantu mempertemukan kebutuhan karyawan akan persetujuan, penghargaan dan keanggotaan. Penilaian positif dari organisasi juga meningkatkan kepercayaan bahwa peningkatan usaha dalam bekerja akan dihargai. Oleh karena itu, karyawan akan memberikan perhatian yang lebih dari penghargaan dari yang mereka terima dari atasan.

Perceived Organizational Support dapat didefinisikan sebagai persepsi karyawan mengenai sejauh mana organisasi memberi dukungan kepada karyawan dan sejauh mana kesiapan organisasi dalam memberikan bantuan saat di butuhkan. Menurut Eisenberger dan Rhoades, perceived organizational support mengacu pada persepsi karyawan mengenai sejauh mana organisasi 
menilai kontribusi mereka dan peduli pada kesejehteraan mereka (Eisenberg \& Rhoades, 2002). Jika karyawan menganggap bahwa dukungan organisasi yang diterimanya tinggi, maka karyawan tersebut akan menyatukan keanggotaan sebagai anggota organisasi ke dalam identitas diri mereka dan kemudian mengembangkan hubungan dan persepsi yang lebih positif terhadap organisasi tersebut. Dengan menyatunya keanggotaan dalam organisasi dengan identitas karyawan, maka karyawan tersebut merasa bagian dari organisasi dan merasa bertanggung jawab untuk berkontribusi dan memberikan kinerja terbaiknya pada organisasinya.

Rhoades dan Eisenberger mengungkapkan persepsi terhadap dukungan organisasi juga dianggap sebagai sebuah keyakinan global yang dibentuk oleh tiap karyawan mengenai penilaian mereka terhadap kebijakan dan prosedur organisasi yang di bentuk berdasarkan pada pengalaman mereka terhadap kebijakan dan prosedur organisasi, penerimaan sumber daya, interaksi dengan agen organisasinya (misalnya supervisor) dan persepsi mereka mengenai kepedulian organisasi terhadap kesejahteraan mereka.

\section{Penghargaan}

Pelaksanaan pekerjaan yang diberikan manajer dan hasil yang diperoleh, maka pekerja mendapat upah atau gaji. Sementara itu, untuk meningkatkan kinerja, manajer menyediakan intensif bagi pekerja yang mendapat memberikan prestasi kerja melebihi standar kinerja yang diharapkan.

Di luar upah, gaji dan intensif, seringkali pemimpin memberikan tambahan penerimaan yang lain sebagai upaya lebih menghargai kinerja pekerjanya. Dengan kata lain, manajemen memberikan penghargaan atau reward. Dalam konsep manajemen, penghargaan merupakan salah satu alat untuk meningkatkan motivasi kinerja para karyawan. Metode ini bisa mengasosiasikan perbuatan dan kelakuan seseorang dengan perasaan bahagia, senang dan biasanya akan membuat mereka melalukan suatu perbuatan baik secara berulang-ulang. Handoko mendefinisikan penghargaan sebagai "bentuk apresiasi usaha untuk mendapatkan tenaga kerja yang profesional sesuai dengan tuntutan jabatan diperlukan suatu pembinaan yang berkeseimbangan, yaitu suatu usaha kegiatan perencanaan, pengorganisasian, penggunaan, dan pemeliharaan tenaga kerja agar mampu melaksanakan tugas dengan efektif dan efisien (Handoko, 2003:485). Sedangkan menurut Nawawi, penghargaan ialah usaha menumbuhkan perasaan diterima (diakui) dilingkungan kerja, yang menyentuh aspek kompensasi dan aspek hubungan antara para pekerja yang satu dengan yang lainnya (Nawawi, 2005:119).

Menyimpulkan pendapat di atas bahwa, penghargaan adalah segala sesuatu apreasi yang menyenangkan perasaan yang diberikan kepada pegawai dengan tujuan agar pegawai tersebut senantiasa melakukan pekerjaan yang baik dan terpuji. Berdasarkan uraian landasan teori diatas dalam tinjauan pustaka, maka model kerangka kajian yang digunakan sebagai berikut: 


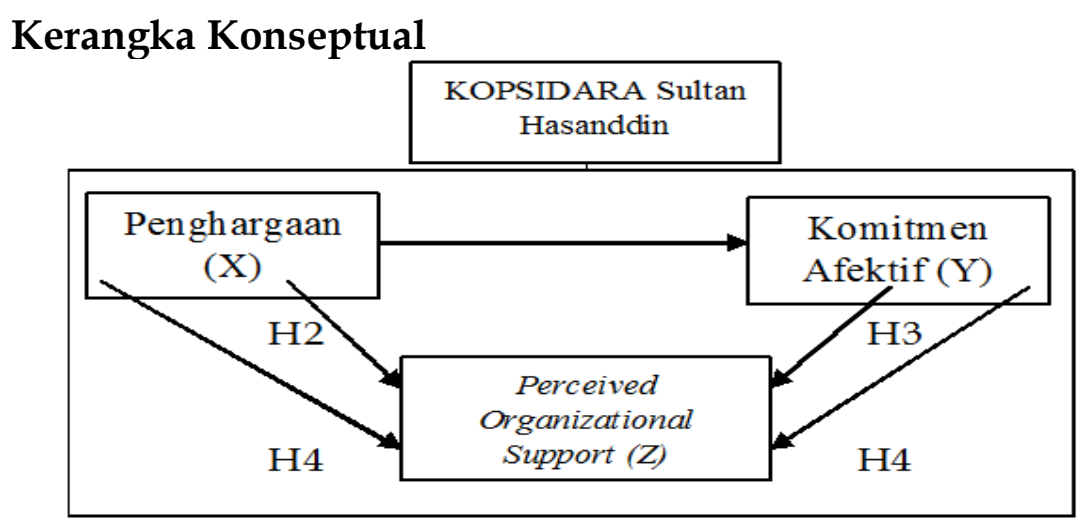

$\mathrm{H} 1$

Kerangka pikir pada penelitian ini dibangun oleh 1 variabel eksogen (exogeneous variables) yaitu variabel penghargaan dan 2 variabel endogen (endogenous variables) yaitu perceived organizational support dan komitmen afektif. Berdasarkan latar belakang, tujuan penelitian dan kerangka pikir, maka dapat disusun hipotesis sebagai berikut:

H1 : Diduga bahwa penghargaan berpengaruh positif dan signifikan terhadap komitmen afektif

H2 : Diduga bahwa penghargaan berpengaruh positif dan signifikan terhadap Perceived Organizational Support.

H3 : Diduga bahwa perceived Organizational Support berpengaruh positif dan signifikan terhadap Komitmen Afektif

H4 : Diduga bahwa penghargaan berpengaruh positif dan signifikan terhadap Komitmen Afektif melalui Perceived Organizational Support.

\section{Jenis dan Lokasi Penelitian}

\section{METODE PENELITIAN}

Jenis penelitian yang dilakukan dalam penelitian ini adalah penelitian kuantitatif. Penelitian kuantitatif adalah penelitian dengan memperoleh data yang berbentuk angka atau data kualitatif yang diangkakan (Sugiono, 2013:14). Lokasi penelitian ini yakni di Koperasi Taksi Bandar Udara (KOPSIDARA) Sultan Hasanuddin yang beralamat di Jln. Poros Maros-Makassar Km. 20 No. 151

\section{Pendekatan Penelitian}

Pendekatan yang digunakan pada penelitian yaitu pendekatan asosiatif. Asosiatif adalah suatu penelitian yang menanyakan sebab akibat antara dua variabel atau lebih (Sugiono, 2013: 61). Pada penelitian ini yang menjadi variabel bebas adalah penghargaan, variabel terikat adalah komitmen afektif dan variabel pemediasi adalah perceived organizational support.

\section{Populasi dan Sampel}

Populasi pada penelitian ini ialah seluruh pegawai KOPSIDARA Sultan Hasanuddin yang berjumlah 17 karyawan dan 185 supir, jadi keseluruhan populasi pada penelitian ini ialah 202 pegawai. Jumlah populasi dalam penelitian ini diketahui secara pasti, maka untuk menentukan jumlah sampel 
dalam penelitian ini menggunakan rumus Slovin, dengan tingkat kelonggaraan ketidaktelitian $\left(\mathrm{e}^{2}\right)$ sebesar 5\%. Berikut rumus penentuan jumlah sampel berdasarkan rumus Slovin sebagai berikut (Ferdinand, 2011: 218).:

$$
n=\frac{\mathrm{N}}{1+\mathrm{N} e^{2}}
$$

Keterangan

$$
\begin{aligned}
& n=\text { jumlah sampel } \\
& \mathrm{N}=\text { Jumlah Populasi } \\
& \mathrm{e}=\text { batas toleransi kesalahan pengambilan sampel sebesar } 5 \% \\
& n=202 / 1+202(0,05)^{2} \\
& n=202 / 1+0,505 \\
& n=134,219
\end{aligned}
$$

Berdasarkan perhitungan diatas, maka peroleh sampel sebanyak 134,219 dibulatkan menjadi 134. Jadi sampel dalam penelitian ini adalah 134 responden. Teknik pengambilan sampel pada penelitian ini menggunakan metode Proportional Random Sampling, yaitu cara pengambilan sampel dengan memperhatikan pertimbangan yang sama dari tiap-tiap bagian di mana populasi dibagi dalam beberapa subpopulasi dan dari tiap subpopulasi diambil proporsi yang sama untuk dipilih sebagai sampel (Nazir, 1983:361). Rumus Proportional Random Sampling menurut Sugiyono adalah sebagai berikut (Sugiono, 2008:75).

$$
s=\frac{\mathrm{Ni}}{\mathrm{n}} \mathrm{xN}
$$

Keterangan:

$$
\begin{array}{ll}
\mathrm{S} & \text { : Ukuran Sampel } \\
\mathrm{Ni} & \text { : Ukuran Populasi } \\
\mathrm{N} & \text { : Ukuran (total) sampel } \\
\mathrm{n} & \text { : Ukuran (total) populasi }
\end{array}
$$

Berikut ini adalah teknik pengambilan sampel dengan proportionate random sampling:

Tabel 1. Kriteria Sampel

\begin{tabular}{|l|l|l|l|l|}
\hline No & Kriteria & Populasi & & Sampel \\
\hline 1. & Karyawan & 17 & $\begin{array}{l}17 / 202 \times \\
134\end{array}$ & 11 \\
\hline 2. & Supir & 185 & $\begin{array}{l}185 / 202 \\
\text { x } 134\end{array}$ & 123 \\
\hline & Total & $\mathbf{2 0 2}$ & & $\mathbf{1 3 4}$ \\
\hline
\end{tabular}




\section{HASIL PENELITIAN DAN PEMBAHASAN}

Hasil

Uji Validitas

Uji validitas mengetahui kelayakan butir-butir dalam suatu daftar (konstruk) pertanyaan dalam mendefinisikan suatu variabel. Untuk menguji valid tidaknya pertanyaan dapat dilakukan melalui program computer Excel Statistc AnalysisE SPSS. Pengujian validitas selengkapnya menunjukkan hasil yang valid.

Uji Realibilitas

Uji Realibilitas merupakan ukuran suatu kestabilan dan konsistensi si responden dalam menjawab hal yang berkaitan dengan konstruk-konstruk pertanyaan yang merupakan dimensi suatu variabel. Alat ukur yang akan digunakan adalah cronbachalpa melalui program computer Excel Statistic Analysis $\mathcal{E}$ SPSS. Hasil uji mengindikasikan reliabilitas seluruh komponen variabel.

Analisis Jalur

Analisis jalur merupakan perluasan dari analisis regresi linear berganda, atau analisis jalur adalah penggunaan analisis regresi untuk menaksir hubungan kausalitas antar variabel (model casual) yang telah ditetapkan sebelumnya berdasarkan teori. Hasil perhitungan menggunakan SPSS yang digunakan sebagai alat analisis maka hasil analisis jalur adalah sebagai berikut:

Tabel 2. Uji t

\begin{tabular}{|c|c|c|c|c|c|}
\hline \multirow[t]{2}{*}{ Model } & \multicolumn{2}{|c|}{$\begin{array}{l}\text { Unstandardized } \\
\text { Coefficients }\end{array}$} & $\begin{array}{c}\text { Standardized } \\
\text { Coefficients }\end{array}$ & \multirow[t]{2}{*}{$\mathrm{T}$} & \multirow[t]{2}{*}{ Sig. } \\
\hline & B & $\begin{array}{l}\text { Std. } \\
\text { Error }\end{array}$ & Beta & & \\
\hline \multirow{2}{*}{$\begin{array}{ll} & \text { (Constant) } \\
\text { X:Penghargaan }\end{array}$} & 7,753 & 1,862 & & 4,165 & ,000 \\
\hline & 787 & ,050 & 808 & 15,742 & 000 \\
\hline
\end{tabular}

a. Dependent Variable: Z:Perceived Organizational Support

Dari tabel diatas, hasil perhitungan maka dapat disusun dengan model persamaan pertama sebagai berikut

$$
Z=7,753+0,787 X+e
$$

Dari persamaan diatas, maka dapat dijelaskan bahwa :

a) Nilai konstan persamaan diatas sebesar 7,753. Hal ini berarti bahwa jika tidak ada Penghargaan (X) maka nilai konsisten Perceived Organizational Support (Z) adalah sebesar 7,753.

b) Penghargaan $(X)$ menunjukkan nilai koefisien sebesar 0,787. Hal ini berarti bahwa jika setiap penambahan $1 \%$ tingkat Penghargaan $(X)$, maka Perceived Organizational Support (Z) akan meningkat sebesar 0,787. 
Tabel 3. Uji t 2 model

\begin{tabular}{|l|r|r|r|r|r|}
\hline & \multicolumn{1}{|r|}{ B } & Std. & Beta & & \\
\hline (Constant) & 20,897 & 1,708 & & & \\
Z: POS &, 287 &, 075 &, 422 & 3,817 &, 000 \\
X: penghargaan &, 183 &, 073 &, 276 & 2,499 &, 014 \\
\hline
\end{tabular}

a. Dependent Variable: Y: Komitmen Afektif

ari tabel diatas, hasil perhitungan maka dapat disusun dengan model persamaan kedua sebagai berikut:

$$
\mathrm{Y}=20,897+0,183 \mathrm{X}+0,287 \mathrm{Z}+\mathrm{e}
$$

Dari persamaan di atas, maka dapat dijelaskan bahwa:

a) Nilai konstan persamaan di atas sebesar 20,897. Hal ini berarti bahwa jika tidak ada Penghargaan $(X)$ dan Perceived Organizational Support (Z) maka nilai konsisten Komitmen Afektif (Y) adalah sebesar 20,897.

b) Penghargaan $(X)$ menunjukkan nilai koefisien sebesar 0,183 . Hal ini berarti bahwa jika setiap penambahan $1 \%$ tingkat Penghargaan $(X)$, maka Komitmen Afektif (Y) akan meningkat sebesar 0,183.

c) Perceived Organizational Support (Z) menunjukkan nilai koefisien sebesar 0,287 . Hal ini berarti bahwa setiap penambahan $1 \%$ tingkat Perceived Organizational Support (Z), maka Komitmen Afektif (Y) akan meningkat sebesar 0,287.

Koefisien Determinasi (Uji R2)

Koefisien determinasi yang dinotasikan dengan $\mathrm{R}^{2}$ merupakan suatu ukuran yang penting dalam regresi, karena dapat menginformasikan baik atau tidaknya model regresi yang terestimasi. Nilai koefisien determinasi $\left(R^{2}\right)$ ini mencerminkan seberapa besar variasi dan variabel terikat $Y$ dapat diterangkan oleh variabel bebas X. Bila nilai koefisien determinasi sama dengan 0 , artinya variasi dari $Y$ tidak dapat diterangkan oleh $X$ sama sekali. Sementara bila $R^{2}=1$, artinya variasi $\mathrm{Y}$ secara keseluruhan dapat diterangkan oleh $\mathrm{X}$ (Manurung \& Pardede, 2014:38). Adapun nilai koefisien determinasi ialah sebagai berikut:

Tabel 4. Kekuatan Hubungan

\begin{tabular}{|l|r|r|r|r|}
\hline Model & $R$ & $R$ Square & $\begin{array}{c}\text { Adjusted R } \\
\text { Square }\end{array}$ & $\begin{array}{r}\text { Std. Error of } \\
\text { the Estimate }\end{array}$ \\
\hline 1 &, $808^{a}$ &, 652 &, 650 & 2,465 \\
\hline
\end{tabular}
a. Predictors: (Constant), X: Penghargaan
b. Dependent Variable: Z: Perceived Organizational Support

Besarnya angka koefisien determinasi (R2) adalah 0,652 atau sama dengan 65,2\%. Angka tersebut mengandung arti bahwa penghargaan berpengaruh terhadap perceived organizational support sebesar 65,2\%. Sedangkan sisanya $(100 \%-65,2 \%=34,8 \%)$ dipengaruhi oleh variabel lain diluar model regresi ini. 
Tabel 5. Uji kekuatan analisis Jalur Model Summaryb

\begin{tabular}{|l|c|c|c|c|}
\hline Model & $\mathrm{R}$ & $\begin{array}{c}\mathrm{R} \\
\text { Squar } \\
\mathrm{e}\end{array}$ & $\begin{array}{c}\text { Adjusted } \\
\text { R Square }\end{array}$ & $\begin{array}{c}\text { Std. Error } \\
\text { of the } \\
\text { Estimate }\end{array}$ \\
\hline 1 &, $666^{\mathrm{a}}$ &, 443 &, 435 & 2,126 \\
\hline
\end{tabular}

a. Predictors: (Constant), $X$ : Penghargaan,

Z: Perceived Organizational Support

b. Dependent Variable: Y: Komitmen Afektif

Besarnya angka koefisien determinasi (R2) adalah 0,443 atau sama dengan 44,3\%. Angka tersebut mengandung arti bahwa penghargaan dan perceived organizational support berpengaruh terhadap komitmen afektif sebesar $44,3 \%$. Sedangkan sisanya $(100 \%-44,3 \%=55,7 \%)$ dipengaruhi oleh variabel lain diluar model regresi ini.

Pengujian Signifikan Parameter Individu

Uji $\mathrm{t}$ adalah untuk menguji apakah setiap variabel bebas (independent) memiliki pengaruh atau tidak terhadap variabel terikat (dependent).Cara melakukan uji $\mathrm{t}$ adalah dengan membandingkan signifikansi $\mathrm{t}$ hitung dengan ketentuan Jika signifikansi $<0,05$ maka Ha diterima dan jika signifikansi $>0,05$ maka Ha ditolak serta dengan membandingkan nilai statistik $t$ dengan $t$ table. Adapun pengujian signifikan parameter individu (uji-t) ialah sebagai berikut:

Tabel 6. Uji t model awal

Coefficientsa

\begin{tabular}{|c|c|c|c|c|c|}
\hline \multirow[t]{2}{*}{ Model } & \multicolumn{2}{|c|}{$\begin{array}{c}\text { Unstandardized } \\
\text { Coefficients }\end{array}$} & $\begin{array}{c}\text { Standardized } \\
\text { Coefficients }\end{array}$ & \multirow[t]{2}{*}{$T$} & \multirow[t]{2}{*}{ Sig. } \\
\hline & B & $\begin{array}{l}\text { Std. } \\
\text { Error }\end{array}$ & Beta & & \\
\hline 1 (Constant) & 7,753 & 1,862 & & 4,165 &, 000 \\
\hline X:Penghargaan & ,787 & ,050 & 808 & 15,742 &, 000 \\
\hline
\end{tabular}

a. Dependent Variable: Z:Perceived Organizational Support

Berdasarkan output Coefficients diatas, diperoleh bahwa nilai thitung sebesar 15,742 $>t_{\text {tabel }} 1,658$ dan nilai signifikansi (Sig.) $0,000<0,05$, dan $\beta=0,787$ bernilai positif, yang artinya bahwa Penghargaan $(X)$ berpengaruh positif dan signfikan terhadap Perceived Organizational Support (Z).

Tabel 7. Uji t model akhir

\begin{tabular}{|c|c|c|c|c|c|}
\hline \multirow[t]{2}{*}{ Model } & \multicolumn{2}{|c|}{$\begin{array}{l}\text { Unstandardized } \\
\text { Coefficients }\end{array}$} & $\begin{array}{l}\text { Standardized } \\
\text { Coefficients }\end{array}$ & \multirow[t]{2}{*}{$\mathrm{T}$} & \multirow[t]{2}{*}{ Sig. } \\
\hline & B & $\begin{array}{l}\text { Std. } \\
\text { Error }\end{array}$ & Beta & & \\
\hline (Constant) & 20,897 & 1,708 & & 12,236 & ,000 \\
\hline Z: POS & ,287 & ,075 & , 422 & 3,817 & ,000 \\
\hline X:Penghargaan & 183 & ,073 & 276 & 2,499 & ,014 \\
\hline
\end{tabular}

a. Dependent Variable: Y: Komitmen Afektif

Berdasarkan output Coefficients diatas, diperoleh bahwa:

a) Nilai thitung sebesar 3,817> $t_{\text {tabel }} 1,658$ dan nilai signifikansi (Sig.) 0,000 < 0,05, dan $\beta=0,287$ bernilai positif, yang artinya bahwa Perceived Organizational 
Support (Z) berpengaruh positif dan signfikan terhadap Komitmen Afektif (Y).

b) Nilai $t_{\text {hitung }}$ sebesar 2,499 $>t_{\text {tabel }} 1,658$ dan nilai signifikansi (Sig.) $0,014<$ 0,05, dan $\beta=0,183$ benilai positif, yang berarti bahwa Penghargaan $(X)$ berpengaruh positif dan signifikan Komitmen Afektif $(\mathrm{Y})$.

Diagram Jalur

Diagram jalur memberikan secara eksplisit hubungan kausalitas antar variabel berdasarkan pada teori. Hasil output SPSS regresi sub struktur 1 memberikan nilai unstandardized beta Penghargaan $(X)$ sebesar 0,787 merupakan nilai path 2 (p2). Sedangkan pada persamaan regresi sub struktur 2, nilai unstandardized beta Penghargaan $(X)$ sebesar 0,183 merupakan nilai path 1 ( $\mathrm{p} 1$ ) dan nilai unstandardized beta Perceived Organizational Support (Z) sebesar 0,287 merupakan nilai path 3 (p3). Besarnya nilai $e 1=\sqrt{(1-0,652)}=0,590$ dan besarnya nilai $e 2=\sqrt{1-0,443}=0,746$.

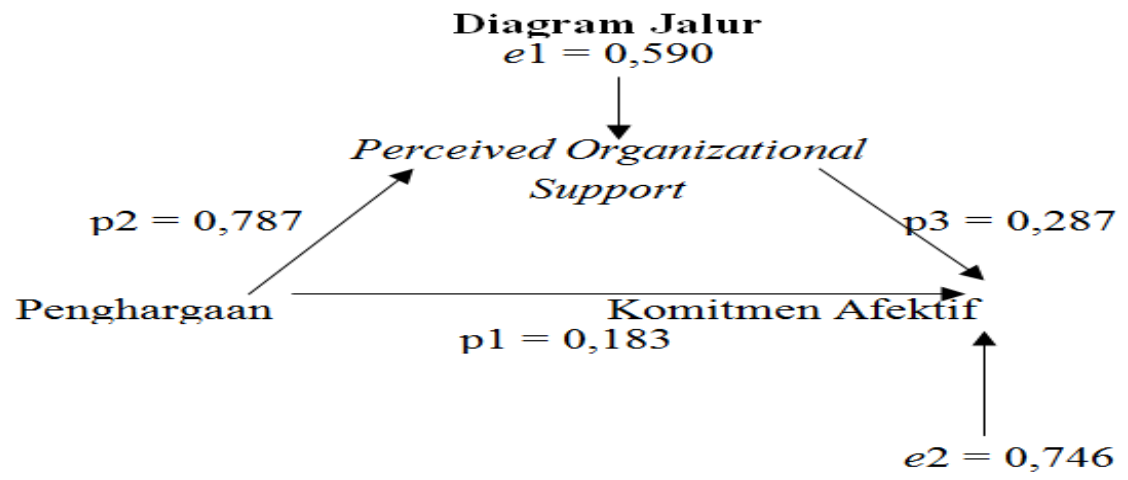

Hasil diagram jalur diatas menunjukkan bahwa Penghargaan $(X)$ dapat berpengaruh langsung ke Komitmen Afektif (Y) dan dapat juga berpengaruh tidak langsung yaitu dari Penghargaan (X) ke Perceived Organizational Support (Z) lalu ke Komitmen Afektif (Y). Besarnya pengaruh langsung adalah 0,183 sedangkan besarnya pengaruh tidak langsung harus dihitung dengan koefisien tidak langsungnya yaitu $(0,787) \times(0,287)=0,226$ dan pengaruh total yang diperoleh yaitu : 0,183 +0,226 $=0,409$.

Pengujian hipotesis mediasi dapat dilakukan dengan prosedur yang uji Sobel (Sobel test) sebagai berikut:

$\mathrm{Sp} 2 \mathrm{p} 3=\sqrt{\mathrm{p}} 3^{2 \mathrm{Sp}} 2^{2+}+\mathrm{p} 2^{2} \mathrm{Sp} 3^{2}+\mathrm{Sp} 2^{2} \mathrm{Sp} 3^{2}$

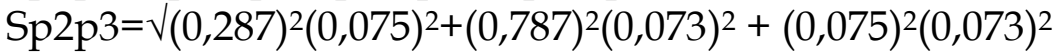

Sp2p3 $=\sqrt{ }(0,021525)+(0,057451)$

$+(0,005475)$

Sp2p3 = 0,084451

Berdasarkan hasil Sp2p3 ini kita dapat menghitung nilai $t$ statistik pengaruh mediasi dengan rumus sebagai berikut:

$t=p 2 p 3 / \operatorname{Sp} 2 p 3=0,226 / 0,084451=2,676$

Oleh karena nilai $t_{\text {hitung }}$ sebesar 2,676 $>t_{\text {tabel }} 1,658$ dan koefisien mediasi 0,226, maka dapat disimpulkan bahwa Perceived Organizational Support (Z) memediasi Penghargaan (X) terhadap Komitmen Afektif (Y) 


\section{Pembahasan}

1. Penghargaan terhadap Komitmen Afektif

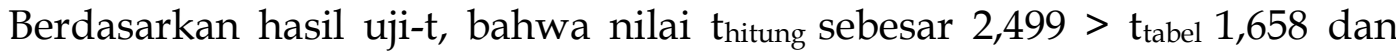
nilai signifikansi (Sig.) 0,014 < 0,05, dan $\beta=0,183$ bernilai positif, yang berarti bahwa Penghargaan $(X)$ berpengaruh positif dan signifikan terhadap Komitmen Afektif (Y). Hal ini mengindikasikan bahwa semakin besar penghargaan yang diberikan oleh Koperasi Taksi Bandar Udara (KOPSIDARA) Sultan Hasanuddin maka akan meningkatkan komitmen afektif karyawan Koperasi Taksi Bandar Udara (KOPSIDARA) Sultan Hasanuddin.

Hal ini sejalan dengan penelitian yang dilakukan Wiwin Mulyani dengan judul "Pengaruh penghargaan terhadap komitmen karyawan di PT. Jasa Marga Persero Cabang Purbaleunyi" bahwa salah satu hal yang menyebabkan rendahnya komitmen tersebut adalah penghargaan yang belum diberikan secara optimal oleh perusahaan. Dari hasil uji hipotesis, diperoleh bahwa variabel penghargaan berpengaruh positif terhadap variabel komitmen karyawan pada PT. Jasa Marga persero cabang Purbaleunyi (Mulyani, 2013). Dengan demikian, berdasarkan pembahasan di atas menunjukkan bahwa $\mathrm{H}_{1}$ diterima.

2. Penghargaan terhadap Perceived Organizational Support

Berdasarkan hasil uji-t, bahwa nilai $t_{\text {hitung }}$ sebesar 15,742 $>t_{\text {tabel }} 1,658$ dan nilai signifikansi (Sig.) 0,000 $<0,05$, dan $\beta=0,787$ bernilai positif, yang artinya bahwa Penghargaan (X) berpengaruh positif dan signfikan terhadap Perceived Organizational Support (Z). Hal ini mengindikasikan bahwa semakin besar penghargaan yang diterima oleh karyawan Koperasi Taksi Bandar Udara (KOPSIDARA) Sultan Hasanuddin maka akan meningkatkan pula dukungan yang diterima oleh karyawan Koperasi Taksi Bandar Udara (KOPSIDARA) Sultan Hasanuddin.

Dari hasil penelitian terdahulu yang dilakukan oleh Andika Ardianto bahwa penghargaan memiliki pengaruh yang signifikan terhadap perceived organizational support pada karyawan PT. POS Persero Surakarta. Hal ini dibuktikan dengan diperoleh hasil analisa model struktural dengan nilai C.R sebesar 2,350 dengan nilai SE 0,043. Karena nilai C.R > dari $\pm 1,96$ menunjukkan adanya pengaruh yang positif antara perceived organizational support terhadap penghargaan. Hal ini mengindikasikan bahwa semakin tinggi tingkat penghargaan yang diberikan oleh perusahaan maka akan mempertebal tingkat perceived organizational support dalam PT. POS Persero Surakarta (Arianto, 2009). Dengan demikian, berdasarkan pembahasan diatas menunjukkan bahwa $\mathrm{H}_{2}$ diterima.

3. Perceived Organizational Support terhadap Komitmen Afektif

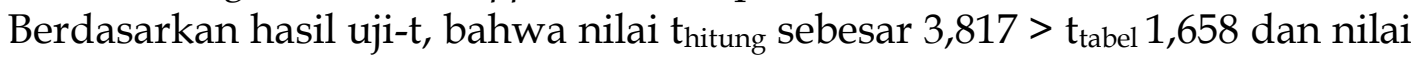
signifikansi (Sig.) 0,000<0,05, dan $\beta=0,287$ bernilai positif, yang artinya bahwa Perceived Organizational Support $(Z)$ berpengaruh positif dan signfikan terhadap Komitmen Afektif (Y). Hal ini mengindikasikan bahwa semakin besar dukungan yang diterima karyawan Koperasi Taksi Bandar Udara 
(KOPSIDARA) Sultan Hasanuddin maka akan meningkatkan komitmen afektif karyawan Koperasi Taksi Bandar Udara (KOPSIDARA) Sultan Hasanuddin.

Dalam penelitian terdahulu yang dilakukan Sia Tjun Han, dkk., bahwa perceived organizational support memiliki pengaruh yang positif dan signifikan terhadap komitmen afektif. Berdasarkan hasil diatas dapat dikatakan bahwa karyawan akan memiliki komitmen yang tinggi apabila karyawan percaya bahwa organisasi akan mendukung dan peduli terhadap karyawan dan apabila organisasi ingin memiliki karyawan dengan komitmen afektif yang tinggi maka organisasi harus menunjukkan komitmen telebih dahulu dengan menyediakan dan mendukung karyawannya dengan baik (Han, 2012). Dengan demikian, berdasarkan pembahasan diatas menunjukkan bahwa $\mathrm{H}_{3}$ diterima.

4. Penghargaan terhadap Komitmen Afektif melalui Perceived Organizational Support.

Berdasarkan hasil diagram jalur, diperoleh nilai $t_{\text {hitung }}$ sebesar 2,676 $>t_{\text {tabel }}$ 1,658, maka dapat disimpulkan bahwa Perceived Organizational Support memediasi penghargaan terhadap komitmen afektif. Dalam penelitian terdahulu yang dilakukan oleh Devina Kristina dkk, bahwa hasil penelitian tersebut menunjukkan pengaruh penghargaan terhadap komitmen afektif dengan organizational support sebagai pemediasi memiliki pengaruh positif dan signifikan. Variabel penghargaan mempunyai pengaruh paling signifikan dibandingkan variabel lainnya. Hal ini dikarenakan pemberian penghargaan dalam bentuk upah, tunjangan dan pengakuan terbukti telah diterima secara nyata dan dirasa sudah cukup baik oleh para karyawan (Kristianti, 2016). Dengan demikian, berdasarkan pembahasan diatas menunjukkan bahwa $\mathrm{H}_{4}$ diterima.

\section{PENUTUP}

Kesimpulan

Berdasarkan uraian hasil analisis dan pembahasan maka dapat disimpulkan bahwa :

1. Berdasarkan hasil analisis, bahwa penghargaan berpengaruh positif dan signifikan terhadap komitmen afektif maka $\mathrm{H}_{1}$ diterima.

2. Berdasarkan hasil analisis, bahwa penghargaan berpengaruh positif dan signfikan terhadap perceived organizational support maka $\mathrm{H}_{2}$ diterima.

3. Berdasarkan hasil analisis, bahwa perceived organizational supportberpengaruh positif dan signfikan terhadap komitmen afektif maka $\mathrm{H}_{3}$ diterima.

4. Berdasarkan hasil perhitungan pengaruh total,yang menunjukkan bahwa perceived organizational support memediasi penghargaan berpengaruh positif dan signifikan terhadap komitmen afektif maka $\mathrm{H}_{4}$ diterima.

Saran

Berdasarkan hasil penelitian yang telah dibahas dan dari penarikan kesimpulan, maka dapat diajukan beberapa saran sebagai berikut :

1. Penelitian ini diharapkan dapat digunakan sebagai salah satu bahan pertimbangan dalam pengambilan kebijakan yang terkait dengan peningkatan komitmen organisasi yang ada di perusahaaan. Dengan harapan bila komitmen terhadap organisasi tersebut tinggi, maka 
perkembangan organisasi akan lebih baik. Selain itu hasil penelitian ini juga dapat digunakan sebagai koreksi mengenai kondisi dan keadaaan yang dirasakan oleh karyawan, sehinggga diharapkan karyawan akan merasa terikat dengan perusahaan secara emosional serta mampu mengidentifikasikan dirinya dengan perusahaan.

2. Penelitian ini diharapkan dapat menambah pengetahuan peneliti dan memperdalam pemahaman atas ilmu yang telah diperoleh dalam kuliah, terutama dalam hal-hal yang terkait dengan penghargaan, komitmen afektif, serta perceived organizational support untuk diaplikasikan dalam organisasi yang digeluti saat ini maupun kelak di dunia kerja.

3. Penelitian ini diharapkan dapat memberikan sumbangan pada pengembangan penelitian dan dapat menjadi acuan untuk penelitianpenelitian selanjutnya mengenai hal-hal yang berkaitan dengan komitmen organisasi afektif.

\section{DAFTAR PUSTAKA}

Ardianto, Andika. "Perceived Organizational Support Sebagai Pemediasi Pengaruh Keadilan Prosedual, Penghargaan, dan Dukungan Supervisor terhadap Komitmen Afektif (Studi Pada Karyawan PT. POS Indonesia (Persero) Kantor POS Surakarta".Skripsi. Surakarta: Fakultas Ekonomi Universitas Sebelas Maret, 2009

Brantas.Dasar-Dasar Manajemen.Cet. Ke-2; Bandung; CV. Alfabeta. 2009

Devina Kristanti, dkk., "Perceived Organizational Support sebagai pemediasi pengaruh Keadilan Prosedural, Penghargaan, Dukungan Supervisor dan Kondisi Kerja terhadap Komitmen Afektif di Restoran Fusia Surabaya", Jurnal Manajemen dan Kewirausahaan, No. 1(2016): h.118-137

Eisenberger, Robert and Rhoades, Linda. "Perceived Organizational Support: A Review of the Literature", Journal of Applied Psychology, Vol. 87, No.4 (2002): h. 698-714

Ferdinand, Augusty. Metode Penelitian Manajemen. Semarang: Universitas Diponegoro. 2011

Ghozali, Imam. Aplikasi Analisis Multivariate Dengan Program SPSS. Semarang: Badan Penerbit Universitas Diponegoro. 2013

Handoko, Hani. Manajemen Sumber Daya Manusia. Edisi ke-2; Yogyakarta: BPFE. 2003

Hasibuan, Malayu S.P.Manajemen Sumber Daya Manusia.Cet. Ke-16; Jakarta: PT. Bumi Aksara. 2012

Hasmarini, Dwi Penny dan Yuniawan, Ahyar. Pengaruh Keadilan Prosedural dan Distributif terhadap Kepuasan Kerja dan Komitmen Afektif. Jurnal Bisnis Strategi, Vol. 17, No. 1 (2008): h. 99-118

Ivancevich, John M, dkk,. Perilaku dan Manajemen Organisasi. Jakarta: PT. Gelora Aksara. 2006

Manurung, Renhard dan Pardede, Ratlan. Analisis Jalur=Path Analysis. Jakarta: Rineka Cipta. 2014 
Meyer, J.P. \& Allen, N.J. "A Three-Component Conceptualization Of Organizational Commitment", Human Resource Management Review, Vol. 1, No. 1 (1991): h. 61-89

Mulyadi dan Setyawan, John. Sistem Perencanaan Pengendalian Management. Jakarta: Penerbit Salemba. 2001

Mulyani, Wiwin. "Pengaruh Penghargaan terhadap Komitmen Karyawan di PT. Jasa Marga Persero CabangPurbaleunyi". Skripsi. Bandung: Universitas Pendidikan Indonesia, 2013

Nawawi, Handari. Manajemen Sumber Daya Manusia. Yogyakarta: Gadjah Mada. 2005

Nugroho, Bhuono Agung. Strategi Jitu: Memilih Metode Statistik Penelitian Dengan SPSS. Yogyakarta: Andi Offset. 2005

Ruslan, Rosady, Metodologi Penelitian: Public Relations dan Komunikasi. Jakarta: PT. Raja. 2003

Sia Tjun Han, dkk., "Komitmen Afektif dalam Organisasi yang dipengaruhi Perceived Organizational Support dan kepuasan kerja", Jurnal Manajemen dan Kewirausahaan, Vol. 14, No. 2 (2012): h. 109-117

Sigit, Soehardi, Esensi Perilaku Organisasional. Yogyakarta: BPFE Universitas Sarjanawiyata Tamansiswa. 2003

Sugiyono. Metode Penelitian Manajemen, Edisi Terbaru. Bandung: Alfabeta. 2013

Sugiyono.Metode Penelitian Kombinasi (Mixed Methods). Cet. Ke-4; Bandung: Alfabeta. 2014

Sutrisno, Edy. Manajemen Sumber Daya Manusia. Jakarta: Kencana Prenada Media Group. 2009

Wibowo. Manajemen Kinerja-Edisi Revisi. Cet. Ke-4; Jakarta: Rajawali Pers. 2014 